\title{
CHANGES IN HEARD ISLAND GLACIERS, KING PENGUINS AND FUR SEALS SINCE 1947
}

\author{
by G. M. Budd
}

(with two tables, three text-figures and one plate)

BUDD, G.M., 2000 (30:vi): Changes in Heard Island glaciers, king penguins and fur seals since 1947. In Banks M.R. \& Brown, M.]. (Eds): HEARD ISLAND Pap. Proc. R. Soc. Tasm. 133 (2): 47-60. https://doi.org/10.26749/rstpp.133.2.47 ISSN 0080-4703. School of Exercise and Sport Science, The University of Sydney, PO Box 170, Lidcombe, NSW, Australia 2141.

The purpose of this paper is to summarise and discuss the changes in glaciers, king penguins and fur seals reported by the nine wintering parties and 11 summer expeditions that have visited Heard Island since 1947, with emphasis upon those of the years between 1947 and 1971. These early years were notable for an initial period (1947-55) of minimal change, and a subsequent period(1963-71) of rapid change in which a complex pattern of asynchronous glacier retreat and readvance was observed and the main features of the island's recolonisation by king penguins and fur seals were established. Subsequent expeditions (1980-93) have reported continuing glacier recession, evidently in response to warmer air temperatures, and a continuing exponential increase in king penguins and fur seals. The glacier observations show that the Heard Island glaciers are sensitive indicators of climate change in the Southern Ocean, and of the interactions between climate and glacier topography. The island's recolonisation by king penguins and fur seals is attributed mainly to an improved food supply which may itself, like the glacier recession, be a response to changes in atmospheric and oceanic circulation. Glacier recession and its consequences are changing the island's coastline, and the expanding populations of king penguins and fur seals are damaging the vegetation. All these phenomena, occurring as they do in an island with a hitherto undamaged ecosystem and no introduced predators, clearly warrant continuing study.

Key Words: expedition history, glacier fluctuations, king penguins, fur seals, recolonisation, habitat preferences, climate change, atmospheric patterns, oceanic circulation patterns, Heard Island.

\section{INTRODUCTION}

Over the past 50 years Heard Island has experienced widespread glacier recession, together with rapid recolonisation by king penguins (Aptenodytes patagonica) and fur seals (Arctocephalus gazella). The most recent observations show that several glaciers now terminate at the head of broad lagoons, $1-2 \mathrm{~km}$ inland from their former coastal ice cliffs (Garvin et al. 1999), and that in 1992-93 there were approximately 11000 breedingpairs of king penguins (Green et al. 1998), 350 fur seal pups (Shaughnessy et al. 1998) and 22000 non-breeding fur seals (Green 1993b).

These changes are interesting in themselves, as largescale and strangely concurrent natural phenomena; in their consequences, which include alterations in the island's coastline and vegetation; and in their potential causes, which include climate change, volcanic activity, and changes in terrestrial and marine ecosystems.

Although the changes in glaciers, king penguins and fur seals have been documented since their beginnings by members of the nine wintering parties and 11 summer expeditions that have visited the island since 1947 (table 1), the information is scattered among numerous papers and reviews that deal with each topic separately. There is no single publication that brings together the evidence on all three. The purpose of this paper, therefore, is to provide a convenient summary and discussion of the observations, with emphasis upon those of the years between 1947 and 1971. These early years were notable for an initial period (1947-55) of minimal change, and a subsequent period (1963-71) of rapid change in which a complex pattern of asynchronous glacier retreat and readvance was observed and the main features of the island's recolonisation by king penguins and fur seals were established. In what follows, the history of expeditions to the island is summarised; the observed changes in glaciers, king penguins and fur seals are described and discussed, together with some of their consequences; and finally their possible causes are considered.

\section{EXPEDITION HISTORY}

Early history (1855-1929)

Heard Island was continuously occupied by sealers for almost three decades after the first landing in 1855 (Downes 1996), and intermittently thereafter until the early 1930s (Roberts 1950, Law \& Burstall 1953). Scientificobservations were made - at the northwestern end of the island only -by the Challenger expedition in 1874 (Thomson \& Murray 1885), by the Gauss expedition in 1902 (Drygalski 1908), and by Aubert de la Rue and the British, Australian and New Zealand Antarctic Research Expedition (BANZARE) in 1929 (Aubert de la Rue 1929, Price 1962).

\section{Continuous ANARE occupation (1947-55)}

From December 1947 until March 1955 Heard Island was continuously occupied by the Australian National Antarctic Research Expeditions (ANARE), which established a station at Atlas Cove (fig. 1) (Scholes 1949, Law \& Burstall 1953, Law \& Bechervaise 1957, Brown 1957, Veenstra \& Manning 1982, Bowden 1997). Work away from the station area was done by unsupported field parties of two or three men travelling on foot, which repeatedly visited most parts of the coast and on two occasions made complete overland circuits. Thus, Spit Bay was visited in November 1948, 1949, 1950 
TAELE 1

Scientific expeditions to Heard Island, 1947-93*

\begin{tabular}{|c|c|c|}
\hline Year & Expedition & References \\
\hline $1947-55$ & $\begin{array}{l}\text { Continuous occupation by ANARE wintering } \\
\text { expeditions at Atlas Cove station }\end{array}$ & $\begin{array}{l}\text { Law \& Burstall 1953, Law \& Bechervaise 1957, } \\
\text { Bowden } 1997\end{array}$ \\
\hline 1963 & ANARE expedition & Budd 1964a, b \\
\hline 1965 & $\begin{array}{l}\text { Private expedition (South Indian Ocean Expedition } \\
\text { to Heard Island) in yacht Patanela }\end{array}$ & Anon 1965, Temple 1966, Tilman 1966 \\
\hline 1969 & ANARE expedition in USCGC Southwind & Budd 1970a \\
\hline 1969-70 & US wintering expedition & Veenstra \& Manning I982 \\
\hline $\begin{array}{l}1971 \\
1980\end{array}$ & $\begin{array}{l}\text { ANARE party with French expedition in M.V. Gallieni } \\
\text { ANARE party with National Mapping expedition } \\
\text { in M.V. Cape Pillar }\end{array}$ & $\begin{array}{l}\text { Gendrin 1971, Budd 1971, 1972a, Bowden } 1997 \\
\text { Veenstra \& Manning } 1982\end{array}$ \\
\hline 1983 & Private expedition (Project Blizzard) in yacht Anaconda II & Vining 1983 \\
\hline 1983 & Private expedition (HIDXA) in whale chaser Cheynes II & Jenkins-Smith 1985, Smith 1986 \\
\hline 1985 & ANARE expedition & Burton \& Williams 1986 \\
\hline $1986-87$ & ANARE expedition & Ledingham 1987 \\
\hline $1987-88$ & ANARE expedition & Kirkwood et al. 1989 \\
\hline 1990 & ANARE early winter expedition & Green 1990a \\
\hline $1992-93$ & ANARE wintering expedition & Green 1993a \\
\hline
\end{tabular}

* Expeditions were undertaken in summer, using ANARE ships, except where otherwise stated. ANARE = Australian National Antarctic Research Expeditions.

and 1951, as well as in July 1951 and December 1954; and Long Beach was visited during the circuit trips of 1951 and 1954.

The period 1947-55 yielded seven years of uninterrupted observations in meteorology and geophysics, and established the main features of the island's topography, geology, glaciology, and biology. It also yielded suggestive evidence of minor glacier recession, and hints of a slight increase in the numbers of non-breeding king penguins and fur seals that were visiting the island.

\section{Subsequent expeditions (1963-93)}

Except for the wintering parties of 1969 and 1992, all subsequent expeditions were undertaken in summer (table 1). The 1963 expedition obtained the first evidence of major glacier retreat and recolonisation by king penguins and fur seals, and the following expeditions recorded the progress of these phenomena. Heard Island is well suited for such studies. It is remote, uninhabited, and infrequently visited by humans; its ecosystem bas not been damaged by past occupation; there are no introduced predators; and it

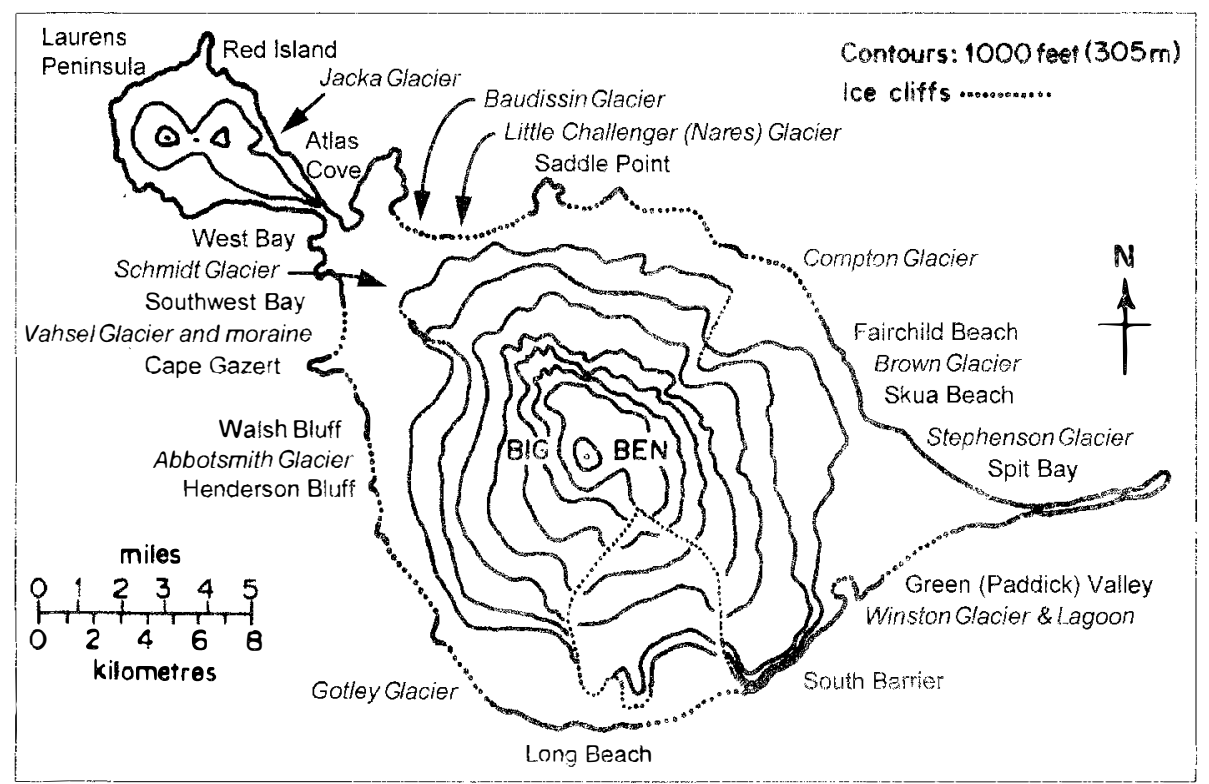

FIG. 1 - Heard Island (1948 map), showing places mentioned in the text. 
presents sharp contrasts of terrain, glacier topography, and local climate.

\section{Methods (1963-71)}

The expeditions of 1963-71 benefited from consistency of field methods, in that the principal investigator took part in all four expeditions (as well as in the 1954-55 expedition and a brief visit in March 1960) and another observer took part in three of them. Glaciers were photographed from the same or similar viewpoints each year, and changes were assessed by reference to adjacent rock features. In these years the numbers of king penguins and fur seals at each locality were still small enough to permit accurate direct counts (confirmed by photography), without the problems, described elsewhere (Budd 1962), that large and dense concentrations of animals present. The techniques used for counting fur seals (Budd 1970c) yielded close agreement between observers and between repeat counts.

\section{CHANGES IN GLACIERS KING PENGUINS AND FUR SEALS}

\section{Glaciers}

\section{Overview (1874-1997)}

The main features of the Heard Island glaciers have been described by Lambeth (1951) and by Allison \& Keage (1986). Photographic and other recordsshowed no apparent change between 1874 and 1929 but suggestive evidence of general minor recession by 1955, and by 1963 there was obvious major recession in most of the glaciers (Budd 1964a,b, Budd \& Stephenson 1970). However, the next eight years brought a mixed pattern of asynchronous retreat and readvance (Budd 1973a), which is summarised in table 2. Subsequent observations (Allison \& Keage 1986 , Garvin et al. 1999) have shown continuing major recession. Details of the observations between 1963 and 1971 are given below.

\section{3}

The greatest change was shown by the Winston Glacier, which had retreated approximately $1.5 \mathrm{~km}$ since 1947 and $0.8 \mathrm{~km}$ since 1954 , and was now divided by a central rock promontory into (a) a southwest stream curving around South Barrier and (b) a northwest ice sheet descending from the eastern side of Big Ben and exposing high rocky bluffs above a beach on Winston Lagoon.

Striking retreat was also obvious elsewhere. On the northeast coast the terminal ice cliffs of the Stephenson and Brown Glaciers, which in 1954 were more than $15 \mathrm{~m}$ high and washed by the sea, had disappeared and the glaciers now terminated more than $100 \mathrm{~m}$ inland behind a beach and a lagoon. The tongue of the Compton Glacier, which in 1947 had extended out into the sea, had receded leaving a line of shoal water that suggested an early stage in the formation of a beach and lagoon.

In Corinthian Bay the Little Challenger Glacier (subsequently renamed the Nares), which in 1954 had terminated in $20 \mathrm{~m}$ sea cliffs, now had a sloping terminus behind a broad beach. The neighbouring Baudissin Glacier showed reduced thickness and lower sea cliffs, and its western tongue - the Schmidt Glacier — was reduced in width and thickness. In Southwest Bay the sea cliffs of the Vahsel Glacier were lower and round-edged, had retreated
TABLE 2

Glacier fluctuations at Heard Island from 1954 to 1971

\begin{tabular}{|c|c|c|c|c|}
\hline \multirow[t]{2}{*}{ Pattern/Glacier } & \multicolumn{4}{|c|}{ Changes* } \\
\hline & 1963 & 1965 & 1969 & 1971 \\
\hline \multicolumn{5}{|l|}{ Continuous retreat } \\
\hline Stephenson & $\mathrm{R}$ & $\mathrm{R}$ & $\mathrm{R}$ & $\mathrm{R}$ \\
\hline Brown & $\mathrm{R}$ & $\mathrm{R}$ & $\mathrm{R}$ & $\mathrm{R}$ \\
\hline Compton & $\mathrm{R}$ & $\dagger$ & $\mathrm{R}$ & $\mathrm{R}$ \\
\hline Jacka & $\mathrm{R}$ & $\dagger$ & $\mathrm{R}$ & $\mathrm{R}$ \\
\hline Schmidt & $\mathrm{R}$ & $\dagger$ & S & $\mathrm{R}$ \\
\hline \multicolumn{5}{|l|}{ Readvance by 1965} \\
\hline Winston - SW stream & $\mathrm{R}$ & A & $\dagger$ & A \\
\hline \multicolumn{5}{|l|}{ Readvance by 1969} \\
\hline Little Challenger (Nares) & $\mathrm{R}$ & $\dagger$ & A & S \\
\hline Baudissin & $\mathrm{R}$ & $\dagger$ & A & $S$ \\
\hline \multicolumn{5}{|l|}{ Readvance by 1971} \\
\hline Vahsel & $\mathrm{R}$ & $\dagger$ & $\mathrm{R}$ & A \\
\hline Abbotsmith & $\dagger$ & $\dagger$ & $\dagger$ & $\mathrm{R} / \mathrm{A}$ \\
\hline Winston - NE sheet & $\mathrm{R}$ & $S$ & $\dagger$ & A \\
\hline
\end{tabular}

* Changes shown are those detected since the previous year of observation, beginning with 1954. R, retreat; S, stationary; A, advance. Table modified from Budd (1973a).

$\uparrow$ Not inspected. Abbotsmith glacier in 1971 was readvancing after having retreated $800 \mathrm{~m}$ since 1954 .

at their northern margin beside Erratic Point, and had developed extensive moraines at their southern margin near Cape Gazert. On the Laurens Peninsula the Jacka Glacier was greatly reduced in thickness, and its terminus had retreated from its 1954 position immediately behind the beach.

\section{5}

Examination of the eastern half of the island showed further retreat of the Stephenson and Brown Glaciers. However, the Winston Glacier's southwestern stream had increased in thickness and readvanced more than $200 \mathrm{~m}$, although its northwestern ice sheet was unchanged.

\section{9}

Examination of all glaciers on the north and northeast coast showed that the Baudissin and Little Challenger had readvanced and now differed little from their 1954 appearance (Budd 1970a, 1973a, Budd \& Stephenson 1970). The Baudissin had increased in thickness, and photographic comparisons with the known height of the adjacent Church Rock showed that the sea cliffs of its eastern part were now $30-40 \mathrm{~m}$ high instead of the $20-25 \mathrm{~m}$ observed in 1963. The Little Challenger had advanced and spread laterally, and had again developed sea cliffs $20 \mathrm{~m}$ high.

Further retreat was apparent in the Stephenson, Brown, Compton, Vahsel and Jacka Glaciers. The ice front of the Brown Glacier had retreated about $300 \mathrm{~m}$ in the six years since 1963. The shoal water observed off the Compton Glacier in 1963 had now developed into a beach, broken in the centre by a wide outlet from a lagoon that was 

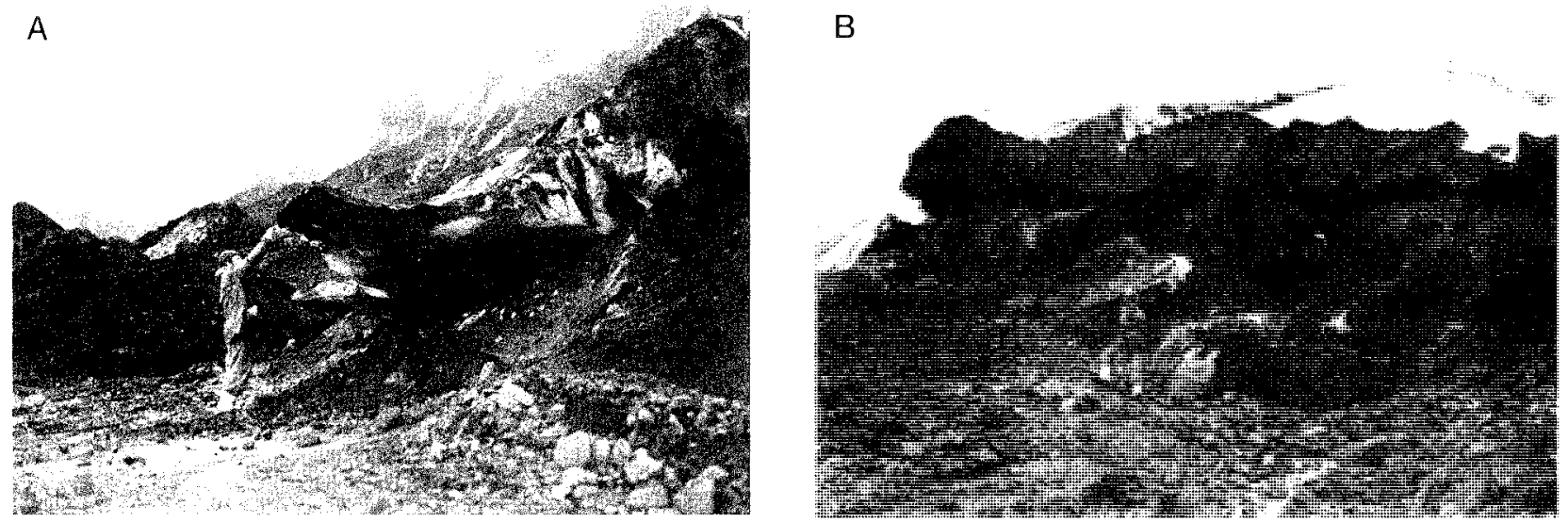

PLATE 1

(A, B) Abbotsmith glacier terminus at Henderson Bluff on 7 February 1971. Both photos show extruded ice slabs, and (B) shows large blocks of fallen ice being overridden by further extrusion. (Photos by G.M. Budd.)

backed by sharp-edged ice cliffs more than $100 \mathrm{~m}$ from the beach.

\section{1}

This year's overland circuit of the island revealed continuing retreat of the Stephenson, Brown, Compton, Schmidt and Jacka Glaciers; no further change in the Baudissin and Little Challenger Glaciers; and strong readvance in the Vahsel Glacier and both parts of the Winston Glacier. It also revealed major recession and subsequent readvance in the Abbotsmith Glacier behind Henderson Bluff, which had not been visited since 1954. Details of these changes follow.

\section{Vahsel Glacier}

The Vahsel Glacier had developed high and sharp-edged sea cliffs which extended closer to Erratic Point and Cape Gazert, and its general appearance resembled that of 1954 .

\section{Abbotsmith Glacier}

The Abbotsmith Glacier reaches the sea in high ice cliffs beneath an ice fall between Walsh Bluff and Henderson Bluff, and also has a sloping terminus on the gravel terrace behind Henderson Bluff. In February 1971 it was found that this land-based terminus had retreated $800 \mathrm{~m}$ since the previous visit in 1954 but was now re-advancing, with broad ice slabs extruding forward for several metres and curving upwards (pl. 1), in some places as far as the vertical plane. Similar featureshave been reported at the terminiof advancing glaciers in Iceland (Heim 1984, 1985, Humlum 1985).

\section{Winston Glacier}

The southwestern stream of the Winston Glacier had advanced a further $200 \mathrm{~m}$ since 1965, and its northwestern. ice sheet was also advancing: the ice above the bluffs, which in 1963 and 1965 had appeared stagnant, was now thicker, had developed sharply defined and overhanging ice cliffs, and showed considerable avalanche activity. Moreover, an ice tongue on the northwestern side of the central rock promontory had thickened, had spread laterally to cover some of the adjacentbluff, and had advanced into the lagoon on a broad front.

Stephenson, Brown and Mary Powell Glaciers

The Stephenson Glacier had developed a lake, several hundred metres wide, at the point where a large meltwater stream flowed through the Dovers moraine to the northern beach of Spit Bay. The Brown Glacier had retreated another $50 \mathrm{~m}$ since 1969. The Mary Powell Glacier above Saddle Point had retreated about $100 \mathrm{~m}$, probably since 1969, and had developed a lake backed by ice cliffs about $6 \mathrm{~m}$ in height.

\section{Summary}

In summary, the observations from 1963 to 1971 (table 2) showed

- continuous retreat of glaciers on the northeast coase (Stephenson, Brown, Compton and Jacka) throughout all eight years;

- readvance through 1965 and 1971 of the southwestern stream of the Winston Crlacier on the southeast coast;

- readvance by 1969 of the north-facing glaciers of Corinthian Bay (Baudissin, Little Challenger), while the Vahsel on the west coast continued to retreat; and

- readvance by 1971 of the Vahsel and Abbotsmith (which had retreated since 1954), and of the northwestern ice sheet of the Winston Glacier, while the Baudissin and Little Challenger showed no further change.

\section{King Penguins}

Early history (1858-1929)

King penguins were abundant in the Spit Bay area of Heard Island in 1858 (Crowther 1970), and according to sealers were still present there in 1929 (Falla 1937). Unfortunately the BANZARE party that spent a week ashore in NovemberDecember 1929 were unable to visit Spit Bay, and in a thorough search at Southwest Bay they found only a single adult king penguin (Falla 1937).

\section{Continuous ANARE occupation (1947-55)}

The first ANARE wintering party found no king penguins at Spit Bay in November 1948, but they did find a small breeding group on the Vahsel moraine in Southwest Bay (Downes et al. 1959). These birds raised two chicks, but most of the colony was removed to Australian zoos in February 1949, owing to an unfortunate failure to appreciate the precarious status of the king penguin at Heard Island. 
Subsequent observations up to March 1955 have been summarised by Downes et al. (1959). There was no further attempt to breed at Vahsel moraine, and only two king penguins were seen on the adjoining beach during a brief visit in March 1960 (Budd, pers. obs.). Wandering individuals and small groups were seen each summer near the ANARE station, and in November 1951 a moulting chick and four other king penguins were seen at Spit Bay. No other evidence of breeding was found at Spit Bay, although field parties had worked there in November in the years 1948,1949, 1950 and 1951, as well as in July 1951 and December 1954. No breeding birds or even groups of more than a few non-breeders had been seen at other parts of the island, although all parties visiting Spit Bay had walked over the northern beaches and two had continued right around the island. Downes et al. (1959) therefore concluded that the occasional birds seen were probably visitors from the large colonies ar Kerguelen, $460 \mathrm{~km}$ to the northwest, and that the king penguin was no longer breeding regularly at Heard Island.

\section{Summer expeditions (1963-71) 1963}

In February and March it was discovered that regular breeding had recommenced (Budd \& Downes 1965). More than 100 king penguins were seen, and 23 of them had eggs or chicks. The two largest colonies, with a total of 37 adults and 20 eggs or chicks, were in the tussock grass behind the north and south beaches at Spit Bay (fig. 2). In addition, single incubating birds were seen on the grassy slopes of Vahsel moraine (near the site of the abandoned 1948 colony) and at Saddle Point, and a well-grown chick of the current summer was seen at Skua Beach.

\section{5}

Observations in the eastern half of the island between 31 January and 5 February showed that the breeding population at Spit Bay had more than doubled since 1963 (Budd 1968), with 81 adults and 45 eggs or chicks present in the two colonies. Single incubating birds were seen at Long Beach and Skua Beach. These figures underestimate the breeding population in 1965, because the counts were made three weeks earlier in the laying period than those of 1963.

\section{9}

Counts in mid-March showed a further doubling of the breeding population in the two Spit Bay colonies, to 153 adults and 86 eggs or chicks (Budd 1970b), and a growth of the Vahsel moraine colony to 40 adults and 17 eggs or chicks. Pairs of adults were also seen at Red Island, West Bay and Atlas Cove; Long Beach was not visited. The total count of 199 adults and 103 eggs or chicks indicated an almost fivefold increase in the breeding population since 1963.

$$
1969-70
$$

On 24 October 1969, members of the American wintering party observed a chick in down, accompanied by eight adults, at Red Island; and on 14 February 1970 they counted 54 adults and 19 eggs or chicks at Vahsel moraine (Ben D. Roth, pers. comim.).

\section{1}

The Vahsel moraine colony, counted on 3 and 26 February, had doubled in size since 1969, with 67 adults and 38 eggs or chicks (Budd 1973b). Breeding had also commenced at
West Bay, whereonebird was found incubating on 8 March; another bird nearby had been incubating a stone since 26 February, presumably because it had lost its egg. No eggs or chicks were seen during searches at Red Island on 31 January and 3 March.

Pattern and rate of increase between 1963 and 1971

Figure 2 summarises the results for Spit Bay and Vahsel moraine (Budd 1975). The north colony at Spir Bay was initially three to four times larger than the south one, but after 1965 the south colony grew more rapidly and the north one more slowly. Consequently the total breeding population at Spit Bay increased almost linearly between 1963 and 1969, at a rate of 11 pairs per year. At Vahsel moraine the pattern of increase paralleled that of the south colony at Spit Bay: both colonies increased exponentially, doubling in size every 2.1 years at Spit Bay south colony and every 1.6 years at Vahsel moraine.

\section{Subsequent observations (1980-93) 1980-87}

Observations at Spit Bay and Vahsel moraine in 1980, 1983, 1985, 1986 and 1987, summarised by Gales \& Pemberton (1988), showed that exponential population growth was continuing, at much the same rate as in 1963-71. These authors calculated that the breeding population at Spit Bay

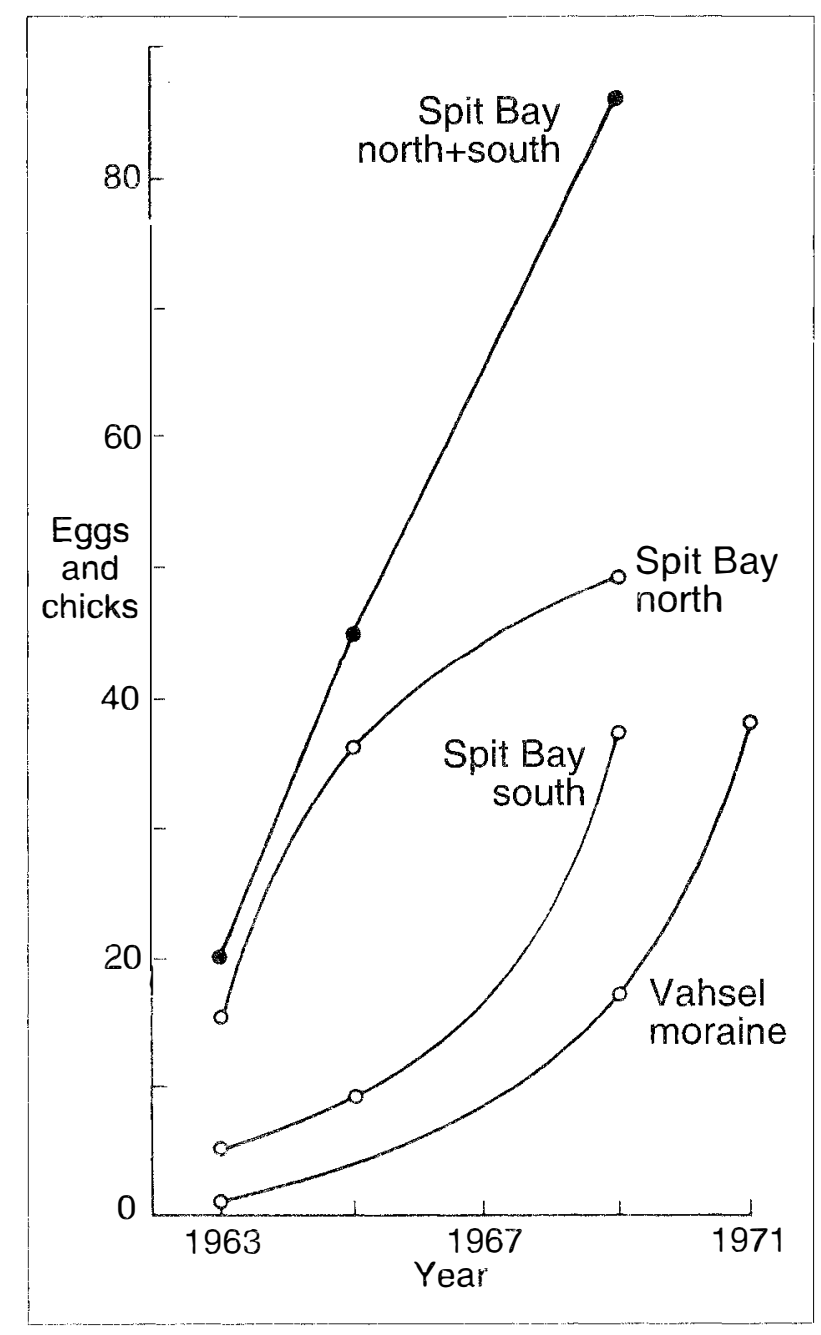

FIG. 2 -- Increases in king penguins from 1963 to 1971 at Spit Bay and Vahsel moraine. (Reproduced, with permission, from Budd 1975.) 
was doubling every 2.7 years at the south colony and every 6.9 years at the north colony. At the Vahsel moraine colony, which between 1980 and 1985 had moved about $1 \mathrm{~km}$ to the vicinity of the Schmidt Glacier, there were 175 eggs on 19 Ja nuary 1987.

1988

At Spit Bay on 16 January 1988 there were 3100 eggs or chicks in the south colony and 215 in the north colony.

\section{0}

In the winter of 1990 a total of 2920 chicks were counted between 22 May and 17 June in four unspecified colonies at the eastern end of Heard Island; 2500 of them were in the Spit Bay south colony (Green \& Wong 1990).

\section{2-93}

Counts at the Vahsel moraine (now Schmidt Glacier) colony in February 1992, andat Spit Bay in February-March 1993 yielded a whole-island total of 10745 breeding pairs, most of which were in the Spit Bay south colony (Green et al. 1998). These findingswould seem to show that the breeding population at Spit Bay increased threefold in the five years 1988-93.

\section{Breeding success to 1971}

Several lines of evidence, summarised below, suggest that in the period 1947--71 few chicks had survived to fledging.

(1) Observations throughout 1969 at Vahsel moraine (Richard Cohen, pers. comm.) appeared to show that only one of the 16 large chicks seen in March had survived to fledging in late November.

(2) "Early breeders" comprised $70 \%$ of the breeding adults seen in 1963 and 90\% of those seen in 1969 and 1971 , although at an established colony in South Georgia they had comprised only 40\% (Stonehouse 1960). Early breeders are birds which had not raised a chick in the previous season, either because they had not attempted to breed (as would be the case with newly arrived immigrants) or else had done so and failed.

(3) No chicks of the previous season were ever seen in the late-summer visits (31 January to 17 March) between 1963 and 1971 , although at South Georgia and the Crozets they may be seen until early March (Stoneho:ıse 1960, Despin, Mougin \& Segonzac 1972). The absence of such chicks at Heard Island, although partly explained by the predominance of early breeders (whose chicks fledge before January), suggested that the chicks of late breeders had all died. This suggestion is consistent with the observation that the single moulting chicks seen at Spit Bay in November 1951 and at Red Jstand in October 1969 were clearly from early breeders and may have been the sole survivors of whatever eggs had been laid that year.

In explanation of this apparently high ratc of breeding failure it was suggested (Budd i975) that the chicks of small colonies would have difficulty in surviving the Heard Island winter because they would be too few to obtain much benefit from huddling together in the colder weather. it would also be expected that the chicks of late breeders would be more vulnerable to cold than those of early breeders because they would be smaller and less mature at the onset of winter.

Recent findings at Kerguelen and Iles Crozet are consistent with the above observations and their interpretation.
Weimerskirch and his colleagues reported that at these islands small colonies of up to 150 pairs of king penguins have produced very few fledglings, or none at all, because of predation by giant petrels on the small huddles of chicks guarded by too few adults (Weimerskirch et al. 1989, 1992, Jouventin \& Weimerskirch 1990). Weimerskirch et al. (1992) concluded that breeding success varies directly with colony size, and that only colonies of more than 200300 pairs produce chicks that are likely to be recruited later as breeding adults. Southern giant petrels (Macronectes giganteus) breed at five places on Heard Island (Downes et al. 1959) and were the main cause of chick deaths during the winter months in 1992 (Moore \& Robertson 1993), although the colonies of king penguins were by then so large that many thousands of chicks nevertheless survived to fledging.

\section{Habitat preference and distribution}

In the first two decades of recolonisation king penguins bred at nearly every beach on Heard Island, usually on the tussock grass (Poa cookii) and azorella (Azorella selago) some hundreds of metres behind the beaches (Budd 1975). At mosr beaches they persisted in breeding for a year or two, with no great increase in their numbers, and then abandoned the site. However, a few sites, such as Spit Bay and Vahsel moraine, seem to have proved especially attractive, and at these sites rapid population growth has ensued.

An interesting reversal of habitat preference occurred at Spit Bay in the first decade of colonisation. In 1963 and 1965 the south colony was only one-quarter the size of the north colony (fig. 2), but thereafter population growth accelerated in the south colony and slowed in the north colony, so that by mid-January 1988 (Gales \& Pemberton 1988 ) there were 14 times as many eggs or chicks in the south colony as in the north (3100 and 215 respectively). Moreover, the finding of king penguin bones at a depth of $45-60 \mathrm{~cm}$ near the south colony (Green 1990b) would seem to show that this site has been used in former times. Why the king penguins should prefer Spit Bay and Vahsel moraine over other localities, and why they switched their preference from the north to the south colony at Spit Bay, are matrers for conjecture, but inspection suggests that the favoured sites are more sheltered than other localities, and at Spit Bay they are sunnier (Budd 1975).

\section{Immigration}

The rapidity of the increase in the numbers of king penguins at Heard Island between 1963 and 1971, despite what appeared to have been a high rate of breeding failure, strongly suggested that the population growth at that time was due, at least in part, to a continuous recruitment of immigrants from some other island. This interpretation was confirmed by the finding that between 31 January and 5 February 1965 there were more juvenile king penguins (birds hatched in early 1963) in the eastern half of Heard Island than there had been eggs or chicks in the whole island in 1963 (Budd 1968); and it was later extended by the conclusion (Weimerskirch et al. 1989) that small colonies of king penguins can grow only through the immigration of birds from large colonies. No king penguins have been seen at the offlying McDonald Islands (Budd 1972a, Johnstone 1982) or Shag Island (Tremont \& Vining 1.983), and the most likely source would seem to be the large colonies at Kerguelen (Budd 1968, Weimerskirch et al. 1989). 
However, Weimerskirch et al.'s findings also implied that since about 1980, when the size of individual colonies at Heard Island first exceeded 300 pairs (Johnstone 1982. Gales \& Pemberton 1988: table 1), local recruitment from successful breeding in these colonies would have made an increasing contribution to population growth, reducing the relative contribution of immigration.

\section{Fur Seals}

\section{Early history (1855-1955)}

Fur seals were present at Heard Island in the 1850s but were virtually exterminated by sealing (Gwynn 1953, Ingham 1960), and until 1947 there were no further reports of their presence. Between 1947 and 1955 they were frequent summer visitors, but the largest concentration seen was 50 seals (at Red Island on 17 February 1954) and there was no firm evidence of breeding. Small seals of about $1 \mathrm{~m}$ in length were occasionally seen, but they were never in their black natal fur and were never seen to suckle, and it is probable as the observers usually concluded - that they were yearlings (Gwynn 1953, Ingham 1960).

\section{Summer expeditions (1963-71) 1963}

Between 19 February and 8 March - the probable time of maximum numbers (Csordas \& Ingham 1965, Shaughnessy \& Goldsworthy 1990) - approximately 500 fur seals were ashore: 464 were counted, and there were probably another 20-30 at the unvisited Green Valley (subsequently renamed Paddick Valley), where 26 were counted in 1965 (Budd \& Downes 1969). The main concentrations were 131 at Red Island, 118 at Fairchild Beach and 126 at Spit Bay.

Iwo pups were seen and photographed while suckling. One of them, still in its black natal fur, was at Red Island on 25 February; the other, already moulted, was at Fairchild Beach on 7 March.

The skulls of two adult males were identified by Miss J.E. King of the Natural History Museum, London, as typical examples of Arctocephalus tropicalis gazella, the southern race of the Kerguelen fur seal (subsequently reclassified as Arctocephalus gazella, the Antarctic fur seal).

\section{5}

Only the eastern half of Heard Island (between the Gotley and Compton Glaciers) was searched, between 31 January and 5 February (Budd \& Downes 1969). Although these searches were made 3-5 weeks earlier than in 1963 and the seasonal haul-out would not have been complete, the counts were already slightly greate than in 1963 , showing that the population had increased. No suckling was seen on this occasion.

\section{9}

Counts at Red Island, Saddle Point, Fairchild Beach, Skua Beach and Spit Bay between 12 and 16 March showed a sixfold increase since 1963 (from 439 to 2662) that was evenly distributed anong the five localities (Budd 1970c). If a similas increase had occurred at the unvisited Green (Paddick) Valley, the total popularion of the island would have been about 3000 seails.

Three pups, two of them suckling, were seen at the western end of Fairchild Beach, lose th the place where suckling was seen in 1963. (This locality, subsequently named "Fur Seal Creek", was the largest breeding site on the island (93 pups) in the summer of 1987--88 Goldsworthy \& Shaughnessy 1989). The pups seen in 1969 had already moulted from their black natal fur, and were accompanied by their mothers, a yearling and a bull. Several more pups were seen at Red Island, making a probable total of six pups for this year.

A plot of the counts made in late February and March at Red Island over the 18 years from 1951 to 1969 (fig. 3) showed that the population there had increased exponentially over this period. When allowance was made for the underestimate, by perhaps $40 \%$, of the maximum population in the early counts of 1965 , it was apparent that exponential population growth had also occurred at Saddle Point, Fairchild Beach, Skua Beach and Spit Bay.

\section{1}

Repeated counts at Red Island on 31 January and 1 February, and two more counts on 3 March, yielded a mean value of 948 seals - 39\% more than the 683 seals counted in the same place on 18 March 1969 (Budd 1972b). There were about a dozen yearlings, and three black pups which were usually accompanied by their mothers and were seen suckling. One of the pups was already moulting on 1 February, but the other two were still in their black coats on 3 March.

Classified counts during this census showed that $84 \%$ of the seals were large bulls more than $1.5 \mathrm{~m}$ in length; most of the remainder, of length $1.0-1.5 \mathrm{~m}$, were thought to be immature males. This distribution was similar to that of other herds on the island in 1971 and previous years, and it showed no obvious change between 1 February and 3 March.

\section{Subsequent observations (1980-93)}

Counts at most localities in February and March in 1980, 1988 and 1992 yielded whole island totals of 4500, 9748 and 21536 fur seals (Johnstone 1982, Goldsworthy \& Shaughnessy 1989, Green 1993b). The numbers of pups counted in the whole island in the summers of 1979-80,

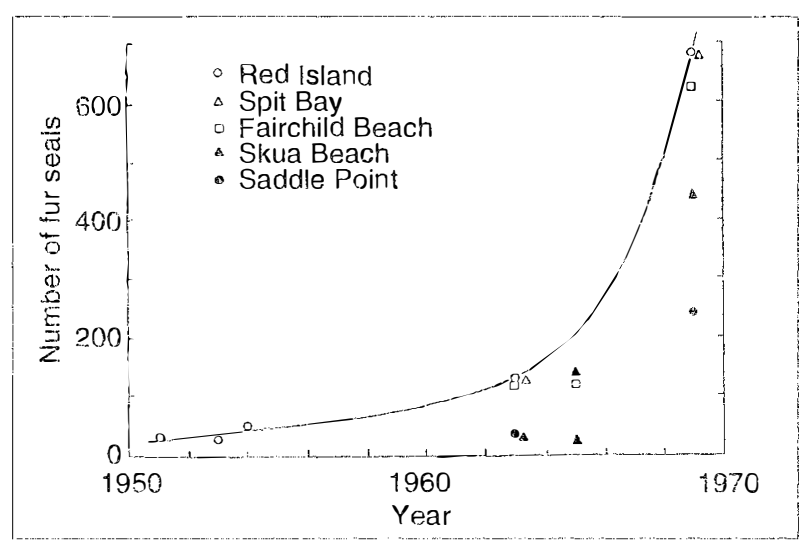

FIG. 3 -... Fur seals on Heard Island at the probable time of maximum numbers (late February and March) 1951--69. Counts made at other times are excluded, except for those of 31. January and I February 1965 (which underestimate the maximum numbers that year). The curve is eye-fitted through the points for Red Island. (Reproduced, with permission, from Budd 1970c.) 
1986-87 and 1987-88 were 46, 172 and 248 (Shaughnessy et al. 1988, Shaughnessy \& Goldsworthy 1990) and the estimated number in 1992-93 was 343 pups (Shaughnessy et al. 1998). These results show that both the breeding and the non-breeding populations have continued to increase exponentially.

\section{Habitat preference and distribution}

The fur seals at Heard Island appear to have shown a strong preference for localities sheltered from wind. In 1963, almost all were on the lee (the northern and eastern) side of the island, many of them in places thatwere further sheltered by hills or moraines (Budd \& Downes 1969) — in contrast to the Subantarctic fur seal Arctocephalus tropicalis at Amsterdam Island, which is reported to prefer the windward coasts (Paulian 1964). Like the fur seals at South Georgia (Bonner 1958, 1968, Boyd 1993) and Marion Island (Rand 1956), the Heard Island seals avoided rocky areas: breeding and non-breeding animals alike occupied the vegetated hills and terraces behind the beaches, sitting or lying on grass tussocks (Poa cookii) or among tall stands of Kerguelen cabbage (Pringlea antiscorbutica). They amicably shared their habitat with elephant seals and with nesting gentoo penguins (Pygoscelis papua), king penguins and giant petrels, although they usually threatened and often charged any men who came near them.

As their numbers increased the fur seals tended to take up localities they had previously avoided, even though there remained room for expansion in the main concentrations - which indeed continued to expand. Such less-favoured (and sometimes less sheltered) localities included Skua Beach, Saddle Point, and the south beach of Spit Bay in 1969 (Budd 1970c); Long Beach, Jacka Glacier and Mt Aubert de la Rue in 1971 (Budd 1972b); and Capsize Beach and Cape Gazert in 1988 (Shaughnessy \& Goldsworthy 1990).

\section{Source of the Heard Island fur seals}

Initially it was assumed (Gwynn 1953, Ingham 1960) that the Heard Island fur seals were summer visitors from either Kerguelen, $466 \mathrm{~km}$ northwest of Heard Island (where they had been abundant before being virtually exterminated by sealers in the 19th century - Allen 1942), or from the McDonald Islands, $54 \mathrm{~km}$ west of Heard Island. However, a review of sightings at Kerguelen since 1951 (Budd \& Downes 1969) showed that fewer fur seals had been seen there than at Heard Island, and that there was no evidence of breeding.

\section{McDonald Islands}

These islands seemed to be a likely source, because they were small, precipitous, inaccessible, and apparently unvisited (Tizard et al. 1885). In these characteristics they resembled the Willis Islands, about $10 \mathrm{~km}$ west of South Georgia, where a relict population that had survived the sealing era was thought to be the source of the fur seals colonising the other islands of the Scotia Ridge (Bonner 1964, 1968). During the first recorded landing on McDonald Island, on 27 January 1971, it was found that under the eastern cliffs a small sandy beach backed by talus, incompletely inspected and photographed from the cliff-tops above, was occupied by at least 46 black fur seal pups, 68 cows and 32 bulls (Budd $1972 \mathrm{a}, \mathrm{b})$. The seals were grouped in seven distinct harems, the largest of which contained 18 cows and 12 pups. Another 53 bulls occupied an adjacent pebble beach.
These observations revealed sharp contrasts in breeding status and habitat between the fur seals of McDonald Island and Heard Island. At McDonald Island at least 68 cows were breeding on one small sandy beach, leaving the adjacent pebble beach to a similar number of non-breeding bulls, whereas at Heard Island an expanding population of 3000 or more, mainly non-breeding bulls, occupied the grassy terraces and hills and, up to that time, had produced only six or so pups each year. It was concluded that the breeding seals at McDonald Island were clearly too few to account for the rapid and continuing increase in the Heard Island population.

A more complete search of McDonald Island, on 12 March 1980 (Johnstone 1982), revealed "up to 100 pups and over 200 others" on the same beaches as in 1971, and showed that there were no other fur seals on the McDonald Islands. The only other potential local source of fur seals was the precipitous Shag Island, $10 \mathrm{~km}$ north of Heard Island, but the first recorded landing, on 26 January 1983, showed that there were no fur seals on the island (Tremont \& Vining 1983).

\section{Kerguelen}

The first breeding colony of fur seals to be reported from Kerguelen since the 19th century was discovered in 1982 at Ile de Croy, one of the Iles Nuages group $20 \mathrm{~km}$ northwest of the northern tip of Kerguelen, where geologists found "a breeding colony of about 1,200 animals" (Jouventin et al. 1982). A biological survey from 17 November to 14 December 1984 revealed "some 1,500 breeding females" and a total estimated population of "over 5,000 animals" (Jouventin \& Stonehouse 1985); a further visit in late summer 1994 yielded a figure of "about 1,900 pups" (Cherel et al. 1997). This colony was considered too small to have provided the influx of summer visitors at Heard Island (Shaughnessy \& Goldsworthy 1990).

\section{South Georgia}

Otherbreeding colonies may eventually be discovered among the numerous islands of the Kerguelen archipelago. However, the sighting at Red Island in March 1971 of an anomalous pale-coated fur seal raised the possibility that the crowded and expanding colonies at South Georgia (Bonner 1968) might be the source of the fur seals at Heard and McDonald Islands (Budd 1972b). Pale coats occur in about $0.1 \%$ of the fur seals at South Georgia and the South Orkney Islands, and the apparent absence of this characteristic from islands outside the Scotia Ridge suggested (Bonner 1964, 1968) that the fur seals of this region may be derived from a single parent population, probably that of South Georgia. Although Bonner (pers. comm.) considered, and recent photographs confirm, that the Heard Island seal was less pale than its counterparts at South Georgia, its presence was nevertheless suggestive, for Csordas (1962) and several later authors (summarised in Shaughnessy \& Goldsworthy 1990) have reported instances of fur seals moving over long distances. Boyd (1993), summarising the results of recent studies of the Antarctic fur seal at all its breeding sites throughout the Southern Ocean, noted that several authors have recognised that many of the fur seals probably derive from the South Georgia population. The results of current genetic studies will clearly be of great interest. 


\section{CONSEQUENCES}

Glacier recession has exposed substantial areas of ice-free terrain, has created several lakes and large coastal lagoons, and has caused changes in coastal currents and sediment transport. These have resulted in severe erosion of some beaches (resulting in the loss of sealers' relics of archaeological value), broadening of other beaches, and changes in orientation of the Spit at the east end of the island (Allison \& Keage 1986, Green 1998). Vegetation has colonised ground newly exposed by retreating glaciers (Scott 1990), while plant distributions elsewhere have changed and new species (e.g. Poa annua) have appeared, apparently as a result of animal disturbance and warmer temperatures (Scott 1989, 1990). Similareffects on vegetation have been observed at Kerguelen, where recently deglaciated areas have been colonised by the introduced grass Poa annua as well as by the native grass P. kerguelensis (Frenot et al. 1997), and at Marion Island, where warmer temperatures are causing complex changes in nutrient cycles (Smith \& Steenkamp 1990).

A potential future dilemma for conservation and management is posed by the expanding populations of king penguins and particularly fur seals at Heard Island, which have already caused substantial damage to tussock grass (Poa cookii) and Kerguelen cabbage (Pringlea antiscorbutica) (Scott 1990), and presumably to other vegetation. The dilemma has been well articulated by Bonner (1985) and Smith (1988, 1990). Although manuring by seals and seabirds constitutes an important source of nutrients for terrestrial ecosystems (Smith 1978), the recovery of fur seal populations to levels probably higher than they were before exploitation is causing widespread and perhaps irreversible damage to lowland vegetation at South Georgia (Bonner 1985) and the South Orkney Islands (Smith 1988, 1990, 1997). At Bird Island on South Georgia, trampling by fur seals and pressure from their lying on tussocks have destroyed large areas of tussock grass (Poa flabellata) and Antarctic hair grass (Deschampsia antarctica), leading to severe erosion of soil and peat, and have deprived six species of birds of breeding habitat and exposed them to predation by skuas (Catharacta lonnbergia). In addition, disturbance by fur seals may have deterred some young wandering albatrosses (Diomedea exulans) from breeding in their natal areas (Croxall et al. 1990). At Signy Island (South Orkneys), the increase in fur seals from "a few dozen" in the early 1970s to 20500 in 1994/95 has caused "widespread devastation" in most lowland terrestrial and freshwater ecosystems (Smith 1988, 1990, 1997). Trampling and the toxicity of excreta and "fur wash" have eradicated extensive communities of mosses and lichens, killed or damaged grasses, caused eutrophication of freshwater lakes, disturbed or eroded lake sediments and moss banks 3000-7000 years old, and destroyed several colonies of giant petrels and Antarctic terns (Sterna vittata).

\section{CAUSES OF THE OBSERVED CHANGES}

\section{Glaciers}

Possible causes of the observed glacier fluctuations include geothermal heat from volcanic activity, and climate change.

\section{Volcanic activity}

Observed activity to 1971, summarised by Budd \& Stephenson (1970), included a major eruption in 1910 (Padang 1963), a flow of incandescent lava near the summit of Big Ben in 1950 — which may have been responsible for long trenches observed beside the upper Abbotsmith and Gotley Glaciers in December 1954 - and intermittent fumarole activity at various levels on the southwestern slopes between 1949 and 1954. However, by February 1963 the trenches had disappeared; crevasse stratigraphy at the $2100 \mathrm{~m}$ level gave no indication that any ash eruptions had occurred for many years; and the summit crater showed only fumarole activity when it was visited for the first time in 1965 (Temple 1966). It was concluded (Budd \& Stephenson 1970) that such intermittent, minor and localised volcanic activity could not explain the widespread glacier retreat that had occurred since 1955. This conclusion has been endorsed by subsequent studies (Allison \& Keage 1986, Ruddell \& Allison 1998); although volcanic activity has intensified in recent years (Williams \& Duhamel 1986, Green 1993c), numerical modelling (Williams 1998) suggests that volcanic activity this century has had a negligible influence on the dynamic behaviour and mass balance of the Heard Island glaciers.

\section{Climate change}

Air temperature

Annual mean air temperature at Heard Island increased by $1.8^{\circ} \mathrm{C}$ between 1948 and 1951 , and in 1954 was still $1.3^{\circ} \mathrm{C}$ higher than in 1948 (Budd \& Stephenson 1970). Similarly, at Kerguelen the mean air temperature throughout the 1950 s was $1.3^{\circ} \mathrm{C}$ higher than the 30 -year mean for $1902-31$ (Budd \& Stephenson 1970); it then decreased by about $0.8^{\circ} \mathrm{C}$ in the early $1960 \mathrm{~s}$, rewarmed by $1.3^{\circ} \mathrm{C}$ between 1964 and 1982, and thereafter remained steady until at least 1991 (Radok \& Watts 1975, Allison \& Keage 1986, Frenot et al. 1993). These changes in air temperature were accompanied by a steady rise in the sea-surface temperature between latitudes $30^{\circ} \mathrm{S}$ and $50^{\circ} \mathrm{S}$, which increased by about $1.0^{\circ} \mathrm{C}$ from the 1930s to the 1980s (Allison \& Keage 1986: fig. 8).

The timing, magnitude and direction of the above fluctuations in air temperature seem adequate to explain the accompanying glacier retreat and readvance of the 1950 s and 1960s at Heard Island and Kerguelen, and the steady retreat that has subsequently occurred at both islands (Budd \& Stephenson 1970, Allison \& Keage 1986, Frenot et al. 1993, Garvin et al. 1999). It is clear that the glaciers of Heard Island are sensitive indicators of regional climate change. Their sensitivity is further demonstrated by the asynchronous timing of the readvances between 1963 and 1971, which presumably was due to interactions between changes in air temperature (and perhaps precipitation and cloud cover) and the individual glaciers' aspect, topography and altitude range (Ruddell \& Allison 1998). 
Causes of changes in air temperature -- atmospheric and oceanic circulation

Loewe et al. (1952) suggested, on the basis of sealers' records from the 1850s, that the wind regime at Heard Island and Kerguelen had changed over the past century. Subsequently, Radok \& Watts (1975) analysed synoptic surface-weather charts for che period 1949-64, and concluded that aboveaverage air temperacures and glacier recession at Heard Island and Kerguelen had occurred ar a time when more low-pressuresystems ("cyclones") werepassing Heard Island on its southern side than on its northern side, and that the reversal of this distribution in rhe 1960s was accompanied by the cooler temperatures and glacier readvances observed at that time. However, a subsequent extension of this analysis to cover the period 1972--81 (Allison \& Keage 1986) showed that the northerlycyclone paths had persisted although air temperature had once again increased. This finding, although reversing the relationship between cyclone paths and air temperature reported by Radok \& Watts (1975), nevertheless confirmed that there had been a "strong and persistent" shift in atmospheric circulation between 1950 and 1980 (Allison \& Keage 1986).

Similar changes in circulation have been inferred at other islands. At Marion Island, Smith \& Steenkamp (1990) reported a strong correlation between air and sea-surface temperatures, which between 1968 and 1985 had increased by $1.6^{\circ}$ and $1.2^{\circ} \mathrm{C}$, respectively, and attributed these changes to changing atmospheric and oceanic circulation patterns in the region. Likewise, at South Georgia, Gordon \& Timmis (1992), analysing synoptic records of atmospheric pressure, attributed rising air temperatures and glacier recession since about 1950 to regional changes in atmospheric circulation. These inferences would seem to be supported by the recent finding (de la Mare 1997) that the summer sea-ice edge around Antarctica abruptly moved southwards by $2.8^{\circ}$ of latitude between the mid $1950 \mathrm{~s}$ and early 1970 s and then stabilised in its new position.

\section{King Penguins and Fur Seals}

Possible causes of the observed recolonisations include recovery from past exploitation, climate change, and an increased food supply.

\section{Recovery from past exploitation}

Although the circumpolar increase in king penguins and fur seals over the past 40 years (Conroy \& White 1973, Croxall et al. 1988, Jouventin \& Weimerskirch 1990, Boyd 1993, Guinet et al. 1996) shows that they clearly are recovering from past exploitation, such exploitation ended at different times among the numerousislands concerned, and recovery from it therefore seems unlikely to be the sole explanation for the present increase at Heard Island.

\section{Climate change - terrestrial effects}

The observation that recolonisation of Heard Island by king penguins and fur seals coincided with a period of major glacier recession naturally raised thequestion whether regional warming might have been partly or wholly responsible for all three phenomena (Budd \& Downes 1965, 1969). The availabie information about the microclimate of king penguin colonies at Heard Island and elsewhere (Budd \& Downes 1965), and their apparently high rate of breeding failure at Heard island between 1963 and 1971, appeared to support an earlier suggestion (Downes et al. 1959) that the Heard Island winter might be too severe for king penguins to raise their chicks. Moreover, the preference of both king penguins and fur seals for sheltered and sunny habitats seemed to show a degree of sensitivity to cold that might previously have discouraged them from colonising Heard Island.

However, evidence to the contrary was provided by historical records of king penguins and fur seals on Heard Island in the 19th century, when the glaciers were not in recession; by the presence of large breeding colonies of fur seals on colder islands such as the South Shetlands, both in the 19rh century (Bonner 1968) and in recent decades (Bonner 1964, Boyd 1993); and by the lack of any obvious effect of the lower air temperarures during the 1960s (Budd 1975). On balance, it appeared unlikely that warmer temperatures on shore had influenced the recolonisation of Heard Îsland by king penguins and fur seals.

\section{Food supply}

The demonstrated importance of immigration to the increase in king penguins and fur seals at Heard Island, and the circumpolar distribution of similar increases at other islands, suggested that the main cause of recolonisation might lie as much with conditions at the migrants' parent colonies, or in the sea, as with conditions at Heard Island itself. It was therefore suggested (Budd \& Downes 1965, 1969, Budd 1975) that the increase was probably a response to an increase in the availability of food, consistent with the suggestion (Sladen 1964) that a concurrent increase in Adelie and chinstrap penguins (Pygoscelis adeliae and $P$. antarctica) might be due to a surplus of krill resulting from the depletion of whale stocks by over-fishing (Mackintosh 1970)

\section{Reduced competition from whales}

Subsequent studies of Antarctic marine ecosystems (e.g. Croxall 1992, Guinet et al. 1996) have generally supported Sladen's suggestion, while also identifying additional causes of population changes in seabirds and seals. Guinet et al. (1996) drew attention to the paradox that although the depletion of whale stocks ought to have mainly benefited predators of crustaceans (such as macaroni penguins, Eudyptes chrysolophus), in fact the highest population growth rates at Crozet and Kerguelen have been in king penguins and fur seals, which in this region feed mainly on pelagic lantern fish (myctophids). In explanation the authors note that Antarctic and Subantarctic myctophids are themselves major consumers of crustaceans, and they suggest that myctophid stocks may have been enhanced by the biomass of crustaceans freed by the removal of baleen whales.

\section{Changes in atmospheric and oceanic circulation} Guinet et al. (1996), in a summary that applies equally well to Heard Island, attributed recent major changes in the populations of seabirds and seals at Crozet and Kerguelen to multiple factors, which include not only recovery from past exploitation and reduced competition from whales but also long-term fluctuations in the abundance and/or availability of the main prey species. Changes in atmospheric and oceanic circulation are major influences on such fluctuations in prey species (Priddle et al. 1988, Croxall 1992, Murphy $\&$ King 1997). Their effects on ice cover near the Antarctic Peninsula have been linked to population changes in Adelie and chinstrap penguins (Fraser et al. 1992); and El NinoSouthern Oscillation (ENSO) events have been associated 
with changes in the populations of fur seals on Crozet, Amsterdam, and St Paul islands (Guinet et al. 1994), with reductions in survival and breeding success of seals and seabirds at South Georgia (Croxall et al. 1988, Priddle et al. 1988), and with fluctuations in the breeding population of elephant seals (Mirounga leonina) in the South Shetland Islands (Vergani \& Stanganelli 1990).

Similar mechanisms, acting over a period of decades rather than years, may explain the changes of the past 50 years in the climate, glaciers, and animal populations of the South Indian Ocean, and possibly of the entire Subantarctic region. The strong and persistent shift in cyclone paths near Heard Island (Radok \& Watts 1975, Allison \& Keage 1986), and the southward movement of the summer sea-ice edge around Antarctica (de la Mare 1997), may both reflect long-term changes in atmospheric and oceanic circulation which have altered marine ecosystems in a way that has improved the food supply of king penguins and fur seals. If this suggestion is correct, then the concurrent changes of the past 50 years in the Heard Island glaciers, king penguins and fur seals may indeed have had a common origin.

\section{CONCLUSIONS}

The Heard Island glaciers have proved to be sensitive indicators of climate change in the Southern Ocean, and of the interactions between climate and glacier topography. The island's recolonisation by king penguins and fur seals is attributed mainly to an improved food supply which may itself, like the glacier recession, be a response to changes in atmospheric and oceanic circulation. Glacier recession and its consequences are changing the island's coastline, and the expanding populations of king penguins and fur seals are damaging the vegetation. All these phenomena, occurring as they do in an island with a hitherto undamaged ecosystem and no introduced predators, clearly warrant continuing study.

\section{ACKNOWLEDGEMENTS}

I a mgrateful to my travelling companions, especially Warwick Deacock, for their help in the fieldwork at Heard Island; to the American and French expeditions of 1969 and 1971 for their hospitality and support; to the Macmillan Press and the editors of Mammalia for permission to reproduce published matter; to Patricia Selkirk, Damian Gore and Jenny Scott for helpful discussions; to the Commonwealth Health Department and the Australian Antarctic Division, which provided supporting funds; and to Phil Law and Don Styles, respectively Director and Deputy Director of the Antarctic Division during the 1950s and 1960s, for their encouragement and support.

\section{REFERENCES}

Allen, G.M., 1942: Extinct and vanishing mammals of the Western Hemisphere, with the marine species of all the oceans. Publ. American Committee International Wild Life Protection, New York.

All.ison, I.F. \& KeAGE, P.L., 1986: Recent changes in the glaciers of Heard Island. Polar Rec. 23: 255-271.
ANON., 1965: Southi Indian Ucean Expedition to Heard 1sland, 1964-65. Polar Rec. 12: 744.

Aubert de LA Rue, E., 1929: Contribution de l'étude géologique de l'île Heard. C. R. Acad. Sci., Paris 189: 129-131.

BONNER, W.N., 1958: Notes on the southern fur seal in South Georgia. Proc. Zool. Soc. Lond. 130: 241-252.

Bonner, W.N., 1964: Population increase in the fur seal, Arctocephalus tropicalis gazella, at South Georgia. In Carrick, R., Prevost, J. \& Holdgate, M.W. (Eds): BIOLOGIE ANTARCTIQUE. Hermann, Paris: 433443.

Bonnf.r, W.N., 1968: The Fur seal of South Georgia. Sci. Rep. Brit. Ant. Surv. 56. British Antarctic Survey, London: $81 \mathrm{pp}$.

Bonner, W.N., 1985: Impact of fur seals on the terrestrial environment at South Georgia. In Siegfried, W.R., Condy, P.R. \& Laws, R.M. (Eds): ANTARCTIC NUTRIENT CYCLES AND FOOD WEBS. SpringerVerlag, Berlin: 641-646.

BOWDEN, T., 1997: THE SILENCE CALLING AUSTRALIANS IN ANTARCTICA 1947-97. Allen \& Unwin, St Leonards, Sydney: 593 pp.

Boyd, I.L., 1993: Pup production and distribution of breeding Antarctic fur seals (Arctocephalus gazella) at South Georgia. Antarct. Sci. 5: 17-24.

Brown, P.L., 1957: TWEEVE CAME BACK. Robert Hale, London: 223 pp.

BudD, G.M., 1962: Population studies in rookeries of the Emperor Penguin Aptenodytes forsteri. Proc. Zool. Soc. Lond. 139: 365-388.

Budd, G.M., 1964a: The ANARE 1963 expeditien to Heard Island. ANARE Rep. 74. Antarctic Division, Departmeni of External Affairs, Melbourne: 53 pp.

Budd, G.M., 1964b: Heard Island expedition, 1963. Polar Rec. 12: 193-195.

BudD, G.M., 1968: Population increase in the King penguin, Aptenodyies patagonica, at Heard Island. Auk 85: 689690.

Buvd, G.M., 1970a: Heard Island reconnaissance, 1969. Polar Rec. 15: 335-336.

BudD, G.M., 1970b: Further population growth in the King penguin, Aptenodytes patagonica, at Heard Island. Auk 87: 366-367.

BudD, G.M., 1970c: Rapid population increase in the Kerguelen Fur seal, Arctocephalus tropicalis gazella, at Heard Island. Mammalia 34: 410-414.

BuDD, G.M., 1971: ANARE 1971 Expedition to Heard Island. Unpubl. rep., 15 July 1971, to Director, Antarct. Div., Dep. Supply, on the work of the "Travelling Party": 21 pp.

BudD, G.M., 1972a: McDonald Island reconnaissance, 1971. Polar Rec. 16: 64-67.

BudD, G.M., 1972b: Breeding of the Fur seal at McDonald Islands, and further population growth at Heard Island. Mammalia 36: 423-427.

Budd, G.M., 1973a: Glacier fluctuations at Heard Island. In Kasser, P. (Ed.): FLUCTUATIONS OF GLACIERS 1965-1970. 1AHS-UNESCO, Paris: 65-68, 163-164.

BudD, G.M., 1973b: Status of the Heard Island King penguins in 1971. Auk 90: 195-196.

Budd, G.M., 1975: The King Penguin at Heard Island. In Stonehouse, B. (Ed): THE BIOLOGY OF PENGUINS. Macmillan, London: 337-352.

BuDD, G.M. \& DownEs, M.C., 1965: Recolonisation of Heard Island by the King penguin Aptenodytes patagonica. Emu. 64: $302-316$.

Budd, G.M. \& Downes, M.C., 1969: Population increase and breeding in the Kerguelen fur seal, Arctocephalus tropicalis gazella, at Heard Island. Mammalia 33: 58-67.

Budd, G.M. \& Stephenson, P.J., 1970: Recent glacier retreat on Heard Island. I $n$ Gow, A.E. et al. (Eds): Proceedings of 
International Symposium on Antarctic Glaciological Exploration (ISAGE), September 1968, Hanover, New Hampshire, USA. Int. Assoc. Sci. Hydrol. (IASH) Publ. 86. Cambridge: 449-458.

Burton, H.R. \& Williams, D.L. (Eds), 1986: Heard Island ANARE 1985 Report. Unpubl. rep. Aust. Antarct. Div., Kingston: $119 \mathrm{pp}$.

Cherel, Y., Guinet, C. \& Tremblay, Y., 1997: Fish prey of Antarctic fur seals Arctocephalus gazella at Ile de Croy, Kerguelen. Polar Biol. 17: 87-90.

Conroy, J.W.H. \& White, M.G., 1973: The breeding status of the king penguin (Aptenodytes patagonica). Brit. Antarct. Surv. Bull. 32: 31-40.

Crowther, W.E.L.H., 1970: Captain J.W. Robinson's narrative of a sealing voyage to Heard Island, 1850-60. Polar Rec. 15: $301-316$

Croxall, J.P., 1992: Southern Ocean environmental changes: effects on seabird, seal and whale populations. Philos. Trans. R. Soc. Lond., Ser. B, 338: 319-328.

Croxall, J.P., McCann, T.S., Prince, P.A. \& Rothery, P., 1988: Reproductive performance of seabirds and seals at South Georgia and Signy Island, South Orkney Islands, 1976-1987: implications for Southern Ocean monitoring studies. In Sahrhage, D. (Ed.): ANTARCTIC OCEAN AND RESOURCES VARIABILITY. Springer, Berlin: 261-285.

Croxall, J.P. Pickering, S.P.C. \& Rothery, P., 1990: Influence of the increasing fur seal population on Wandering Albatrosses Diomedea exulans breeding on Bird Island, South Georgia. In Kerry, K.R. \& Hempel, G. (Eds): ANTARCTIC ECOSYSTEMS: ECOLOGICAL CHANGE AND CONSERVATION. Springer-Verlag, Berlin: 237-240.

Csordas, S.E., 1962: The Kerguelen fur seal at Macquarie Island. Vict. Nat. 79: 226-229.

Csordas, S.E. \& Ingham, S.E., 1965: The New Zealand fur seal, Arctocephalus forsteri (Lesson), at Macquarie Island, 194964. CSIRO Wildl. Res. 10: 83-99.

DE LA MARE, W.K., 1997: Abrupt mid-twentieth-century decline in Antarctic sea-ice extent from whaling records. Nature Lond. 389: 57-60.

Despin, B., Mougin, J.-L. \& Segonzac, M., 1972: Oiseaux et mammifères de l'Ile de l'Est. CNFRA 31: 106 pp.

DOWNES, M.C., 1996: Indexing sealers' logbooks from Heard Island. ANARE Res. Notes 97: 96 pp.

Downes, M.C., Ealey, E.H.M., Gwrnn, A.M. \& Young, P.S., 1959: The Birds of Heard Island. ANARE Rep., Ser. B, 1. Antarctic Division, Department of External Affairs, Melbourne: 135 pp.

DryGALSKI, E. von, 1908: Geographievon Heard Eiland. Deutsche Sudpolar Expedition, 1901-1903. Bd. II, Geogr. Geol. 3: 225-239.

Falla, R.A., 1937: Birds. Rep. BANZ Antarct. Res. Exped. 192931, Ser. B, 2: 288 pp.

Fraser, W.R., Trivelpiece, W.Z., Ainley, D.G. \& Trivelpiece, S.G., 1992: Increases in Antarctic penguin populations: reduced competition with whales or a loss of sea ice due to environmental warming? Polar Biol. 11: 525-531.

Frenot, Y., Gloaguen, J.C., Picot, G., Bougere, J. \& Benjamin, D., 1993: Azorella selago Hook. used to estimate glacier flucuations and climatic history in the Kerguelen Islands over the last two centuries. Oecologia 95: 140-144.

Frenot, Y., Gloaguen, J.C. \& Trehen, P., 1997: Climate change in Kerguelen Islands and colonization of recently deglaciated areas by Poa kerguelensis and P. annua. In Battaglia, B., Valencia, J. \& Walton, D.W.H. (Eds): ANTARCTIC COMMUNITIES: SPECIES, STRUCTURE AND SURVIVAL. Cambridge, University Press: 358-366.

Gales, R. \& Pemberton, D., 1988: Recovery of the King Penguin, Aptenodytespatagonica, population on Heard Island. Aust. Wildl. Res. 15: 579-585.
Garvin, J.B., Mahmood, A. \& Gigulere, C., 1999: Taking a clear look at cloud covered $\bullet$ ceanic islands on a seasonal basis. EOS, Trans., Am. Geophys. Un. 80: 49-54.

Genorin, R., 1971: Rapport sur la mission Franco-Australienne a L'He Heard (Janvier-Mars 1971). Unpubl. rep. Groupe de Rech. Ionos. (Paris).

Goldowmorthy, S.D. \& Sthucinnessy, P.D., 1989: Counts of the Antarctic fur seal Arctocephalus gazella and location of cølonies at Heard Island in the 1987-88 suinmer. ANARE Res. Notes 72. Antarctic Division, Kingston. 25 pp.

Gordon, J.E. \& Timmis, R.J., 1992: Glacier fluctuations on South Georgia during the 1970 s and early 1980s. Antarct. Sci. 4: $215-226$

Green, K. (Ed.), 1990a: Heard Island 1990 ANARE Report. Unpubl. rep. Aust. Antarct. Div., Kingston: 75 pp.

Green, K., 1990b: Summary of bird observations. In Green, K. (Ed.): Heard Island 1990 ANARE Report.. Unpubl. rep. Aust. Antarct. Div., Kingston: 55-56.

Green, K. (Ed.), 1993a: Heard Island 1992 ANARE Report.. Unpubl. rep., Aust. Antarct. Div., Kingston: 208 pp.

GreEN, K., 1993b: Counts for biomass calculations of Antarctic fur seals (Arctocephalus gazella) at Heard Island, 1992/93. In Green, K. (Ed.): Heard Island 1992 ANARE Report. Unpubl. rep., Aust. Antarct. Div., Kingston: 11-13.

Green, K., 1993c: Volcanic activity. In Green, K. (Ed.): Heard Island 1992 ANARE Report. Unpubl. rep. Aust. Antarct. Div., Kingston: 175-176.

GreEn, K., 1998: Coastal landform changes at Heard Island. In Selkirk, P. (Ed.): HEARD ISLAND WILDERNESS RESERVE: REPORTS ON NATURAL SCIENCE AND CULTURAL HERITAGE RESEARCH. ANARE Res. Notes 101. Antarctic Division, Kingstor: 17-18.

Green. K. \& WonG, V., 1990: King penguin numbers at Heard Island. In Green, K. (Ed.), 1990: Heard Island 1990 ANARE Report. Unpubl. rep. Aust. Antarct. Div., Kingston: 54 .

Green, K., Slip, D.J. \& Moore, G.J., 1998: The take of fish species by seabirds and marine mammals in the Australian Fishing Zone around Heard Island: the potential for competition with a commercial fishery. Polar Biol. 20: 273-280.

Guinet, C., Jouventin, P. \& Georges, J-Y., 1994: Long term population changes of fur seals Arctocephalus gazella and Arctocephalus tropicalis on subantarctic (Crozet) and subtropical (St. Paul and Amersterdam) islands and their possible relationship to El Nino Southern Oscillation. Antarct. Sci. 6: 473-478.

Guinet, C., Cherel, Y., Ridoux, V. \& Jouventin, P., 1996: Consumption of marine resources by seabirds and seals in Crozet and Kerguelen waters: changes in relation to consumer biomass 1962-85. Antarct. Sci. 8: 23-30.

GWYNN, A.M., 1953: Notes on the fur seals at Macquarie Island and Heard Island. ANARE Interim Rep. 4.

HeIm, D., 1984: Stauchmoränengenese durch die Entwicklung eines "Gletscherfusses" am Kötlujökull, Sudisland. Polarforschung 54: 21-36.

Heim, D., 1985: Genesis of the Push Moraine at Kötlujökull, Iceland: A Reply. Polarforschung 55: 130-132.

Humzum, O., 1985: Genesis of the Push Moraine at Kotlujokull, Iceland: A Commentary. Polarforschung 55: 127-129.

Ingham, S.E., 1960: The status of seals (Pinnipedia) at Australian Antarctic stations. Mammalia 24: 422-430.

JenKINS-SMITH, K., 1985: HEARD ISLAND ODYSSEY. HIDI"Y" Enterprises, Norfolk Island: 148 pp.

Johnstone, G.W., 1982: Zoology. In Veenstra, C. \& Manning, J. (Eds): Expedition to the Australian Territory of Heard Island and McDonald Islands 1980. Dep. Natl Dev. Energy Canberra, Tech. Rep. 31: 33-39.

Jouventin, P. \& Stonehouse, B., 1985: Biological survey of Ile de Croy, Iles Kerguelen, 1984. Polar Rec. 22: 688-691.

Jouventin, P. \& W F.MMERSKIRCH, H., 1990: Long-term changes in seabird and seal populations in the Southern Ocean. 
In Kerry, K.R. \& Hempel, G. (Eds): ANTARCTIC ECOSYSTEMS: ECOLOGICAL CHANGE AND CONSERVATION. Springer-Verlag, Berlin: 208-213.

Jouventin, P., Stahl, J.C. \& Weimerskirch, H., 1982: La recolonisation des Iles Crozet par les otaries (Arctocephalus tropicalis et A. gazella). Mammalia 46: 505-514.

Kirkwood, R.J., Woehler, E.J. \& Burton, H.R. (Eds), 1989: ANARE Report Heard Island 1987-1988. Unpubl. rep. Austr. Antarct. Div., Kingston.

LAMBETH, A.J., 1951: Heard Island: geography and glaciology. J. Proc. Roy. Soc. NSW 84: 92-98.

LAw, P.G. \& BECHERVAISE, J.M., 1957: ANARE - AUSTRALIA'S ANTARCTIC OUTPOSTS. Oxford University Press, Melbourne: $152 \mathrm{pp}$.

Law,P.G. \& Burstall, T., 1953: Heard Island. ANARE Interim Rep. 7: 32 pp.

LEDingham, R. (Ed.), 1987: Heard Island Expedition ANARE 1986-87. Unpubl. rep., Aust. Antarct. Div., Kingston: $180 \mathrm{pp}$.

Loewe, F., Radok, U. \& Grant, A., 1952: Eine säkulare Klimaanderung im südlichen Indischen Ozean? Ber. Dtsch Wetterdienstes US-Zone, Bad Kissingen 42: 11-15.

Mackintosh, N.A., 1970: Whales and krill in the twentieth century. In Holgate, M.W. (Ed.): ANTARCTIC ECOLOGY. Vol. 1. Academic Press, London: 195-212.

Moore, G.J. \& Robertson, G.G., 1993: Population parameters of the king penguin (Aptenodytes patagonicus) at Heard island over the 1992 and 1993 breeding seasons: population size, patterns of chick mortality, fledging patterns and morphometrics. In Green, K. (Ed): Heard Island 1992 ANARE Report. Unpubl. rep., Aust. Antarct. Div., Kingston: 67-70.

Murphy, E. \& KING, J., 1997: Icy message from the Antarctic. Nature Lond. 389: 20-21.

Padang, M. Neuman van, 1963: The volcanoes of the southern part of the Indian Ocean. In CATALOGUE OF THE ACTIVE VOLCANOES OF THE WORLD INCL UDING SOLFATARA FIELDS. PT XVI. Arabia and the Indian Ocean. International Association of Volcanology.

Paulian, P., 1964: Contribution a l'étude de l'otariae de l'île Amsterdam. Mammalia 28, Suppl 1: 1-146.

Price, A.G., 1962: THE WINNING OF AUSTRALIAN ANTARCTICA - MAWSON'S B.A.N.Z.A.R.E. VOYAGES 1929-1931. Angus and Robertson, Sydney: $241 \mathrm{pp}$.

Priddle, J., Croxall, J.P., Everson, I., Heywood, R.B., Murphy, E.J., Prince, P.A. \& Sear, C.B., 1988: Large-scale fluctuations in distribution and abundance of krill - a discussion of possible causes. In Sahrhage, D. (Ed.): ANTARCTIC OCEAN AND RESOURCES VARIABILITY. Springer, Berlin: 169-182.

RADOK, U. \& WATTS, D., 1975: A synoptic background to glacier variations of Heard Island. In Snow and Ice Symposium - Neiges et Glaces (Proceedings of the Moscow Symposium, August 1971; Actes du Colloque de Moscou, aout 1971): IAHS-AISH Publ. 104: 42-56.

Ran®, R.W., 1956: Notes on the Marion Island fur seal. Proc. Zool. Soc. Lond. 126: 65-82.

Roberts, B.B., 1950: Historical notes on Heard and McDonald Islands. Polar Rec. 5: 580-584.

Rudnell, A. \& Allison, I., 1998: The sensitivity of glaciers at Heard Island to climatic change, and their recent response. In Selkirk, P. (Ed): HEARD ISLAND WILDERNESS RESERVE: REPORTS ON NATURAL SCIENCE AND CULTURAL HERITAGE RESEARCH. ANARE Res. Notes 101. Antarct. Div., Kingston: 32.

SCHOLES, A., 1949: FOURTEEN MEN - STORY OF THE AUSTRALIAN ANTARCTIC EXPEDITION TO HEARD ISLAND. Cheshire, Melbourne: 273 pp.

ScotT, J.J., 1989: New records of vascular plants from Heard Island. Polar Rec. 25: 37-42.
SCOTT, J.J., 1990: Changes in vegetation on Heard Island 1947 1987. In Kerry, K.R. \& Hempel, G. (Eds): ANTARCTIC ECOSYSTEMS: ECOLOGICAL CHANGE AND CONSERVATION. Springer-Verlag, Berlin: 61-76.

Shauginessy, P.D. \& Golosworthy, S.D., 1990: Population size and breeding season of the Antarctic fur seal Arctocephalus gazella at Heard Island - 1987/88. Mar. Mamm. Sci. 6: 292-304.

Shaughnessy, P.D., Shaughinessy, G.L. \& Ke.acie, P.L., 1988 Fur-seals at Heard Island: recovery from past exploitation? In Augee, M.L. (Ed): MARINE MAMMAIS OF AUSTRALASIA - FIELD BIOLOGY AND CAPTIVE MANAGEMENT. Royal Zoological Society of New South Wales: 71-77.

Shaughnessy, P.D., Erb, E. \& Green, K., 1998: Continued increase in the population of Antarctic fur seals, Arctocephalus gazella, at Heard Island, Southern Ocean. Mar. Mamm. Sci. 14: 384-389.

SLAdEN, W.J.L, 1964: The distribution of the Adelie and chinstrap penguins. In Carrick, R., Prevost, J. \& Holdgate, M.W. (Eds): BIOLOGIE ANTARCTIQUE. Hermann, Paris: 359-365.

SMITH, J., 1986: SPECKS IN THE SOUTHERN OCEAN. University of New England, Armidale: 108 pp.

SMITH, R.I. LEWIS, 1988: Destruction of Antarctic terrestrial ecosystems by a rapidly increasing fur seal population. Biol. Conserv. 45: 55-72.

SMiTH, R.I. LEwIS, 1990: Signy Island as a paradigm of biological and environmental change in Antarctic terrestrial ecosystems. In Kerry, K.R. \& Hempel, G. (Eds): ANTARCTIC ECOSYSTEMS: ECOLOGICAL CHANGE AND CONSERVATION. Springer-Verlag, Berlin: 32-50.

Smith, R.I. LewIS, 1997: Impact of an increasing fur seal population on Antarctic plant communities: resilience and recovery. In Battaglia, B., Valencia, J. \& Walton, D.W.H. (Eds): ANTARCTIC COMMUNITIES SPECIES, STRUCTURE AND SURVIVAL. Cambridge, University Press: 433-436.

SMiтH, V.R., 1978: Animal-plant-soil nutrient relationships on Marion Island (Subantarctic). Oecologia 32: 239-253.

Smith, V.R. \& SteenKamp, M., 1990: Climatic change and its ecological implications at a subantarctic island. Oecologia 85: 14-24.

Stonehouse, B., 1960: The King penguin Aptenodytes patagonica of South Georgia. I. Breeding behaviour and development. Sci. Rep. Falkld Isl. Depend. Surv. 23: 81 pp.

TEMPLE, P., 1966: THE SEA AND THE SNOW - THE SOUTH INDIAN OCEAN EXPEDITION TO HEARD ISLAND. Cassell Australia, Melbourne: 188 pp.

Thomson, C.W. \& Murray, J., 1885: REPORT ON THE SCIENTIFIC RESULTS OF THE VOYAGE OF H.M.S CHALLENGER DURING THE YEARS 1873-76, NARRATIVE. Vol. 1, Part 1. London, H.M. Stationery Office.

TILMAN, H.W., 1966: MOSTLY MISCHIEF - VOYAGES TO THE ARCTIC AND TO THE ANTARCTIC. Hollis \& Carter, London: 191 pp.

Tizard, T.H., Moseley, H.N., Buchanan, J.Y. \& Murray, J., 1885: McDonald Islands. In CHALLENGER SCIENTIFIC REPORTS, NARRATIVE, Vol. 1 (1): 368-369.

Tremont, S. \& Vining, R., 1983: Penguins - abundance and distribution. In Vining, R. (Ed.), 1983: HEARD ISLAND EXPEDITION 1983 - SCIENTIFIC REPORTS. Garvan Institute of Medical Research, Sydney: 19-20.

Veenstra, C. \& Manninc( J. J. (Eds), 1982: Expedition to the Australian Territory of Heard Island and McDonald Islands 1980. Dep. Natl Dev. Energy Canberra, Tech. Rep. 31: 69 Pp.

Vergani, D.F. \& Stanganelli, Z.B., 1990. Fluctuations in breeding populations of elephant seals Mirounga leonina 
at Stranger Point, King George Island 1980-1988. In Kerry, K.R. \& Hempel, G. (Eds): ANTARCTIC ECOSYSTEMS: ECOLOGICAL CHANGE AND CONSERVATION. Springer-Verlag, Berlin: 241-245.

VINING, R. (Ed.), 1983: HEARD ISLAND EXPEDITION 1983 - SCIENTIFIC REPORTS. Garvan Institute of Medical Research, Sydney: 55 pp.

Weimerskirch, H., Zotier, R. \& Jouventin, P., 1989: The avifauna of the Kerguelen Islands. Emu 89: 15-29.

Weimerskirch, H., Stahl, J.C. \& Jouventin, P., 1992: The breeding biology and population dynamics of King
Penguins Aptenodytes patagonica on the Crozet Islands. Ibis 134: 107-117.

Williams, G.D., 1998: Numerical modelling of the response of Heard Island glaciers to climate change. Unpubl. BSc Hons thesis, Inst. Antarct. South. Ocean Stud., Univ. Tasm., Hobart.

Williams, R. \& Duhamel, G., 1986: Volcanic activity on Heard Island. Polar Rec. 23: 88-90.

(accepted 5 July 1999) 